\title{
Teaching Quality Assessment of College English Department Based on Factor Analysis
}

\author{
https://doi.org/10.3991/ijet.v16i23.27827 \\ Zhihao $\mathrm{Wu}^{1}$, Hui $\mathrm{Li}^{1}\left({ }^{\varpi}\right)$, Xinyu Zhang ${ }^{1}$, Zhili $\mathrm{Wu}^{2}$, Shuting $\mathrm{Cao}^{1}$ \\ ${ }^{1}$ Cangzhou Normal University, Cangzhou, China \\ ${ }^{2}$ Cangzhou Technical College, Hebei, China \\ wzh1986@caztc.edu.cn
}

\begin{abstract}
The English departments in colleges and universities are the training center of professional English talents. Their teaching quality bears on the international exchanges and economic development. Through questionnaire survey, interview, and literature review, this paper designed an evaluation index system (EIS) for teaching quality assessment of English departments in colleges and universities, which consists of 19 indexes. Specifically, the collected data was computed and sorted out through factor analysis, and the common factors were extracted, forming an EIS containing 19 secondary indices and 5 primary indices. Next, a weight was assigned to each index in the EIS. Taking the English departments of 3 higher educational schools in a province for example, an empirical analysis was carried out to verify the application effect of our EIS on the teaching quality of college English education. The results demonstrated the scientific nature, reasonability, and feasibility of the proposed EIS. The research enriched the theoretical and practical evidences for the teaching quality assessment of college English education, and promotes the teaching quality assessment of college English department.
\end{abstract}

Keywords-factor analysis, colleges, English department, teaching quality assessment

\section{$1 \quad$ Introduction}

In the context of global economic integration, China has implemented the reform and opening-up policy, and Chinese people have paid more attention to the learning of English as a lingua franca, as a result, the status of English teaching in higher education has been elevated [1]. To equip China with English talents for future global competition, colleges and universities in China have successively set up the English departments, who have cultivated a bunch of English major graduates in these years, however, the quality of these graduates is not satisfactory. Therefore, the assessment of the teaching quality of college English department has become an important and urgent task for English educators to improve English teaching quality and the comprehensive quality of English graduates [2]. 
In western countries, the development of education assessment has gone through three stages. The first stage was from the mid-nineteenth century to the 1930s, which can be called the germination period; during this time, the teaching quality and the students' ability are evaluated based on personal experience and subjective impressions, and there's no standardized and objective assessment system [3]. The second stage was from the 1930s to the 1950s, which can be called the formation period, education assessment during this time is more comprehensive, more evaluation methods have been developed, including the classic "Tyler Evaluation Model" [4]. The third stage is from the 1950 s to the present, which can be called the heyday stage, education assessment during this time is greatly valued by people, research on education assessment is extensive, and the modes, objects, methods, and forms of education assessment are much more comprehensive and diverse [5]. In China, the imperial examination system originated in the Sui Dynasty is the rudiment of education assessment, in later stage, due to the aggression of imperialist countries, there's a blank period in China's education assessment development [6]. After the founding of the new China, especially after the 1990s, the Chinese government has gradually emphasized more on education, the progress of educational reform has been promoted continuously, great research achievements have been made in terms of education assessment, and the EIS of teaching quality of higher education has been optimized continuously [7].

Drawing on the relevant research results at home and abroad, this paper took the teaching quality evaluation of college English departments as the research object, and adopted factor analysis to construct an EIS for assessing the teaching quality of college English department, then, the paper verified the feasibility and application effect of the proposed EIS through empirical analysis.

\section{About the factor analysis}

\subsection{Mathematical model of factor analysis}

The main purpose of factor analysis is to find out the main factors that can affect the research object, this method groups the variables, and describes and reflects the research object with a few variables [8]. Assuming the number of observed samples is $\mathrm{N}$, each sample can be described by $\mathrm{P}$ indexes, and $x=(x 1, x 2, \cdots x p)$, then the mathematical model of factor analysis can be expressed by Formula 1 [9]:

$$
\left\{\begin{array}{c}
x_{1}=a_{11} F_{1}+a_{12} F_{2}+\cdots+a_{1 m} F_{m}+\varepsilon_{1} \\
x_{2}=a_{21} F_{1}+a_{22} F_{2}+\cdots+a_{2 m} F_{m}+\varepsilon_{2} \\
\cdots \cdots \\
x_{p}=a_{p 1} F_{1}+a_{p 2} F_{2}+\cdots+a_{p m} F_{m}+\varepsilon_{p}
\end{array}\right.
$$

It can also be expressed as a matrix: 


$$
\left(\begin{array}{c}
x_{1} \\
x_{2} \\
\cdots \\
x_{p}
\end{array}\right)=\left(\begin{array}{cccc}
a_{11} & a_{12} & \cdots & a_{1 m} \\
a_{21} & a_{22} & \cdots & a_{2 m} \\
\cdots & \cdots & \cdots & \cdots \\
a_{p 1} & a_{p 2} & \cdots & a_{p m}
\end{array}\right)+\left(\begin{array}{c}
\varepsilon_{1} \\
\varepsilon_{2} \\
\cdots \\
\varepsilon_{p}
\end{array}\right)
$$

Which can be written as:

$$
X=A F+\varepsilon
$$

Table 1 shows the meaning of each index in the formula and the conditions that the model needs to meet [10].

Table 1. Meaning of each index in the formula

\begin{tabular}{|l|l|}
\hline \multicolumn{1}{|c|}{ Index } & \multicolumn{1}{c|}{ Meaning } \\
\hline $\mathrm{F}_{1}, \mathrm{~F}_{2}, \ldots, \mathrm{F}_{\mathrm{m}}$ & Common factor \\
\hline$\varepsilon_{1}, \varepsilon_{2}, \ldots, \varepsilon_{\mathrm{p}}$ & Special factor \\
\hline $\mathrm{a}_{\mathrm{ij}}$ & Factor load \\
\hline Conditions that the model needs to meet & Meaning \\
\hline 1. $\mathrm{m}<\mathrm{p}$ & $\begin{array}{l}\text { The number of common factors is less than the number of } \\
\text { original variables }\end{array}$ \\
\hline 2. $\operatorname{cov}(F, \varepsilon)=0$ & $\mathrm{~F}$ and $\varepsilon$ are not related \\
\hline 3. $\operatorname{var}(F)=\operatorname{Im}$ & $\mathrm{F}_{1}, \mathrm{~F}_{2}, \ldots$ Fm are not correlated, and the variances are all 1 \\
\hline 4. $\operatorname{var}(\varepsilon)=\operatorname{diag}\left(\sigma 1^{2}, \sigma 2^{2}, \cdots \sigma p^{2}\right) a i j$ & $\varepsilon_{1}, \varepsilon_{2}, \ldots, \varepsilon_{\mathrm{p}}$ are not correlated and have different variances \\
\hline
\end{tabular}

\subsection{Steps of factor analysis}

Specific steps of applying factor analysis in teaching quality assessment are [11]:

1. Extract evaluation indexes

Extract corresponding evaluation indexes according to the content to be studied.

2. Establish a matrix of the evaluation indexes

Select $n$ evaluators to evaluate using the $\mathrm{p}$ indexes, then obtain the initial evaluation data matrix [12]:

$$
X=\left[\begin{array}{cccc}
X_{11} & X_{12} & \cdots & X_{1 n} \\
X_{21} & X_{22} & \cdots & X_{2 n} \\
\cdots & \cdots & \cdots & \cdots \\
X_{p 1} & X_{p 2} & \cdots & X_{p n}
\end{array}\right]
$$

3. Data normalization

Use formula 5 to normalize the data [13]:

$$
Y_{i j}=\left(X_{i j}-\bar{X}_{j}\right) / \sqrt{\operatorname{Var}\left(X_{j}\right)}
$$




\section{Applicability test}

Use KMO and Bartlett's test to test the applicability of the factor analysis method. In the Bartlett's test, if sig $<0.05$ and $\mathrm{KMO}>0.5$, then the factor analysis method is applicable. Table 2 gives the value ranges of KMO for judging whether the factor analysis method is applicable or not [14].

Table 2. Value ranges of KMO for judging whether factor analysis is applicable

\begin{tabular}{|l|c|}
\hline \multicolumn{1}{|c|}{ KMO value range } & Whether factor analysis is applicable \\
\hline$>0.9$ & Highly applicable \\
\hline $0.8 \sim 0.9$ & Very applicable \\
\hline $0.7 \sim 0.8$ & Applicable \\
\hline $0.6 \sim 0.7$ & Generally suitable \\
\hline $0.5 \sim 0.6$ & Not applicable \\
\hline$<0.5$ & Not applicable at all \\
\hline
\end{tabular}

5. Determine and name the common factors

After determining the mathematical model of the factor analysis method, the least square method, the maximum likelihood estimation, or the principal component analysis could be adopted to find out the common factors and name them, this paper adopted the principal component analysis method [15].

6. Calculate scores of the factors

Calculate the score of each factor and normalize the data of the indexes to obtain the weights of indexes at all levels.

\section{Teaching quality assessment of college English department based on factor analysis}

\subsection{Content design of evaluation indexes}

English teaching in colleges and universities is a complete system, many factors can affect the teaching quality. To assess the teaching quality comprehensively and objectively, this study combined questionnaire survey with interview method, and took English teachers (including the dean, deputy dean, director of the academic affairs office, academic affairs administrator, and English teacher) and English major students from 35 colleges and universities as respondents to investigate the factors that can affect the teaching quality of college English departments. A total of 60 teacher questionnaires and 500 student questionnaires were issued, and 59 and 492 valid questionnaires were returned respectively.

After sorting out and analyzing the survey data, statistical results of the teachers' and students' answers for the question "What factors do you think can affect the teaching quality of college English department?" are shown in Figures 1 and 2, in teachers' opinion, four aspects can affect the teaching quality, including the faculty, management, teaching, student learning and employment; while in students' opinion, 
factors can affect the teaching quality are the teachers' teaching ability, teaching method, teaching attitude, students' employment rate, and certificate pass rate, etc.

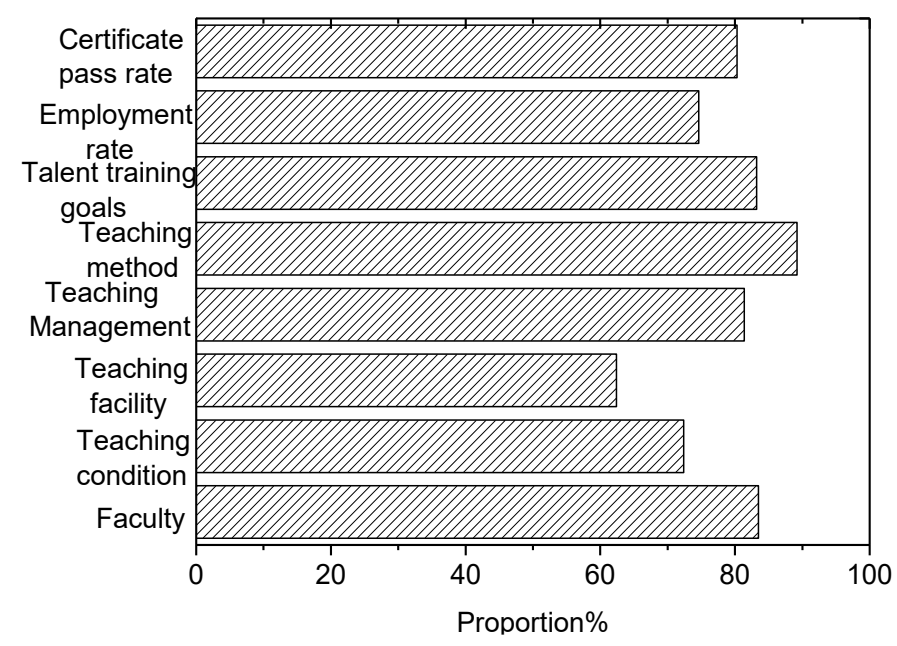

Fig. 1. Survey results of teacher respondents

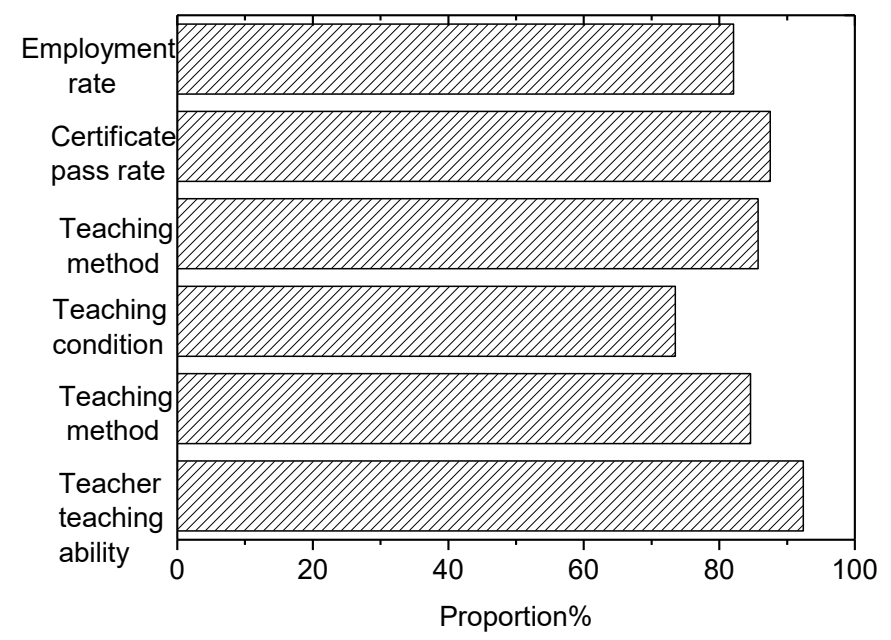

Fig. 2. Survey results of student respondents

Based on the survey and interview results, this paper referred to the talent cultivation assessment plans of colleges and universities in China and relevant research results of teaching quality assessment $[16,17]$, and finally determined the following evaluation indexes for assessing the teaching quality of college English department, as listed in Table 3 [18]. 
Table 3. Proposed evaluation indexes

\begin{tabular}{|l|c|}
\hline \multicolumn{1}{|c|}{ Assessment content } & Serial number \\
\hline Teacher qualifications & $\mathrm{X} 1$ \\
\hline Talent training goals & $\mathrm{X} 2$ \\
\hline Curriculum & $\mathrm{X} 3$ \\
\hline Teaching content & $\mathrm{X} 4$ \\
\hline Book information & $\mathrm{X} 5$ \\
\hline Academic structure & $\mathrm{X} 6$ \\
\hline Management System & $\mathrm{X} 7$ \\
\hline Teaching file & $\mathrm{X} 8$ \\
\hline Teaching experience & $\mathrm{X} 9$ \\
\hline teaching method & $\mathrm{X} 10$ \\
\hline Teaching attitude & $\mathrm{X} 11$ \\
\hline Pass rate of English test (CET-4, CET-6, CET-4 for & $\mathrm{X} 12$ \\
\hline English majors, CET-8 for majors) & $\mathrm{X} 13$ \\
\hline Teaching assessment method & $\mathrm{X} 14$ \\
\hline Implementation of the teaching plan & $\mathrm{X} 15$ \\
\hline Student graduation rate & $\mathrm{X} 16$ \\
\hline Student employment rate & $\mathrm{X} 17$ \\
\hline Student satisfaction & $\mathrm{X} 18$ \\
\hline Employer satisfaction & $\mathrm{X} 19$ \\
\hline Multimedia Classroom & \\
\hline
\end{tabular}

\subsection{EIS construction}

According to above-mentioned steps of factor analysis, the survey data was sorted out and input into the SPSS software, after calculation, the Bartlett's test reached the significant level, the KMO was 0.798 , the value was between 0.7 and 0.8 , indicating that factor analysis was applicable for the obtained data. After factor analysis, 5 common factors that can affect the teaching quality of college English department were extracted, the cumulative contribution rate of the 5 common factors was $74.5 \%$, indicating that these indexes can represent the teaching quality of English department to a certain extent, and Table 4 shows the structure of the factors obtained after factor analysis.

Table 4. Factor structure

\begin{tabular}{|l|c|c|}
\hline Common factor & Index name & Latent variable \\
\hline F1 & X1.X6.X9 & Faculty \\
\hline F2 & X2.X3.X7.X8 & Teaching Management \\
\hline F3 & X5.X19 & Teaching condition \\
\hline F4 & X4.X10.X11.X14 & Teaching process \\
\hline F5 & X12.X13.X15.X16.X17.X18 & Teaching effect \\
\hline
\end{tabular}


After the structure of the factors was determined, the EIS was constructed, and the weight of each index was calculated, the results are shown in Table 5.

Table 5. The proposed EIS, indexes, and weights

\begin{tabular}{|c|c|c|c|}
\hline $\begin{array}{l}\text { Primary } \\
\text { index }\end{array}$ & Weight & Secondary index & Weight \\
\hline \multirow{3}{*}{ Faculty } & \multirow{3}{*}{0.17} & Teacher qualifications & 0.32 \\
\hline & & Academic structure & 0.31 \\
\hline & & Teaching experience & 0.37 \\
\hline \multirow{4}{*}{$\begin{array}{l}\text { Teaching } \\
\text { Management }\end{array}$} & \multirow{4}{*}{0.18} & Talent training goals & 0.25 \\
\hline & & Curriculum & 0.23 \\
\hline & & Teaching file & 0.18 \\
\hline & & Management System & 0.34 \\
\hline \multirow{2}{*}{$\begin{array}{l}\text { Teaching } \\
\text { condition }\end{array}$} & \multirow{2}{*}{0.15} & Multimedia Classroom & 0.51 \\
\hline & & Book information & 0.49 \\
\hline \multirow{5}{*}{$\begin{array}{l}\text { Teaching } \\
\text { process }\end{array}$} & \multirow{5}{*}{0.24} & Teaching method & 0.17 \\
\hline & & Teaching attitude & 0.2 \\
\hline & & Teaching content & 0.24 \\
\hline & & Teaching assessment method & 0.21 \\
\hline & & Implementation of the teaching plan & 0.18 \\
\hline \multirow{5}{*}{$\begin{array}{l}\text { Teaching } \\
\text { effect }\end{array}$} & \multirow{5}{*}{0.26} & Student graduation rate & 0.12 \\
\hline & & Student employment rate & 0.24 \\
\hline & & Student satisfaction & 0.18 \\
\hline & & Employer satisfaction & 0.32 \\
\hline & & $\begin{array}{l}\text { Pass rate of English test (CET-4, CET-6, CET-4 for English majors, CET- } \\
8 \text { for majors) }\end{array}$ & 0.14 \\
\hline
\end{tabular}

\subsection{Application of the proposed EIS}

To verify the feasibility of the proposed EIS, this study selected the English departments of 3 different types of higher educational schools as research objects (object $\mathrm{A}$ is a 985-project university; object $\mathrm{B}$ is a key undergraduate college; object $\mathrm{C}$ is a general undergraduate college); at the same time, 30 English expert educators, education administrators, and teachers were invited to give assessment to the teaching quality of research objects according to the proposed EIS. Some of the assessment data (such as the satisfaction of students, and the satisfaction of employer units) was the history survey data provided by each school, experts were asked to score each index, which was then divided into five grades according to its score, that is: excellent (90-100 points), good (80-89 points), average (70-79 points), pass (60-69 points), and fail (0-59 points) [19]. Table 6 shows the statistics of the assessment scores of the English departments of schools A, B, and C. 
Paper-Teaching Quality Assessment of College English Department Based on Factor Analysis

Table 6. Assessment scores of the English departments of schools A, B, and C

\begin{tabular}{|c|c|c|c|c|c|c|c|c|c|}
\hline \multirow{2}{*}{$\begin{array}{c}\text { Primary index and } \\
\text { weight }\end{array}$} & \multicolumn{3}{|c|}{ Score } & \multirow{2}{*}{ Secondary index and weight } & \multicolumn{2}{|c|}{ Score } & \multicolumn{3}{|c|}{$\begin{array}{l}\text { Comprehensive } \\
\text { score }\end{array}$} \\
\hline & $A$ & $B$ & $C$ & & $A$ & \begin{tabular}{|l|l|}
$B$ & $C$ \\
\end{tabular} & $A$ & $B$ & $C$ \\
\hline \multirow{3}{*}{$\begin{array}{l}\text { Faculty } \\
(0.17)\end{array}$} & \multirow{3}{*}{91.01} & \multirow{3}{*}{83.33} & \multirow{3}{*}{80.68} & Teacher qualifications $(0.32)$ & 92 & \begin{tabular}{|l|l}
85 & 80 \\
-1
\end{tabular} & \multirow{19}{*}{88.91} & \multirow{19}{*}{84.75} & \multirow{19}{*}{83.19} \\
\hline & & & & Academic structure $(0.31)$ & 90 & \begin{tabular}{l|l|}
82 & 81 \\
\end{tabular} & & & \\
\hline & & & & Teaching experience $(0.37)$ & 91 & \begin{tabular}{|l|l|}
83 & 81 \\
\end{tabular} & & & \\
\hline \multirow{4}{*}{$\begin{array}{l}\text { Teaching Manage- } \\
\text { ment } \\
(0.18)\end{array}$} & \multirow{4}{*}{89.31} & \multirow{4}{*}{83.26} & \multirow{4}{*}{83.65} & Talent training goals $(0.25)$ & 89 & \begin{tabular}{|l|l|}
79 & 84 \\
\end{tabular} & & & \\
\hline & & & & Curriculum $(0.28)$ & 93 & \begin{tabular}{l|l|}
85 & 82 \\
\end{tabular} & & & \\
\hline & & & & Teaching file $(0.13)$ & 88 & \begin{tabular}{|l|l|}
91 & 83 \\
\end{tabular} & & & \\
\hline & & & & Management System (0.34) & 87 & \begin{tabular}{|l|l|}
82 & 85 \\
\end{tabular} & & & \\
\hline \multirow{2}{*}{$\begin{array}{l}\text { Teaching condition } \\
(0.15)\end{array}$} & \multirow[b]{2}{*}{88.94} & \multirow{2}{*}{89.57} & \multirow[b]{2}{*}{86.04} & Multimedia Classroom $(0.51)$ & 86 & \begin{tabular}{|l|l|l}
93 & 88 \\
\end{tabular} & & & \\
\hline & & & & Book information (0.49) & 92 & \begin{tabular}{|l|l|l}
86 & 84
\end{tabular} & & & \\
\hline \multirow{5}{*}{$\begin{array}{l}\text { Teaching process } \\
(0.24)\end{array}$} & \multirow{5}{*}{87.4} & \multirow{5}{*}{88.23} & \multirow{5}{*}{88.9} & Teaching method $(0.17)$ & 81 & \begin{tabular}{|l|l|}
84 & 91 \\
\end{tabular} & & & \\
\hline & & & & Teaching attitude $(0.2)$ & 92 & \begin{tabular}{|l|l|}
90 & 91 \\
\end{tabular} & & & \\
\hline & & & & Teaching content $(0.24)$ & 85 & \begin{tabular}{|l|l|}
93 & 84 \\
\end{tabular} & & & \\
\hline & & & & $\begin{array}{c}\text { Teaching assessment method } \\
(0.21)\end{array}$ & 87 & 8389 & & & \\
\hline & & & & $\begin{array}{l}\text { Implementation of the teaching } \\
\text { plan }(0.18)\end{array}$ & 92 & \begin{tabular}{l|l}
90 & 91
\end{tabular} & & & \\
\hline \multirow{5}{*}{$\begin{array}{l}\text { Teaching effect } \\
(0.26)\end{array}$} & \multirow{5}{*}{88.66} & \multirow{5}{*}{80.72} & \multirow{5}{*}{77.6} & Student graduation rate $(0.12)$ & 95 & \begin{tabular}{|l|l|}
92 & 84 \\
\end{tabular} & & & \\
\hline & & & & Student employment rate $(0.24)$ & 92 & \begin{tabular}{|l|l|}
85 & 73 \\
\end{tabular} & & & \\
\hline & & & & Student satisfaction $(0.18)$ & 84 & \begin{tabular}{|l|l|}
82 & 78 \\
\end{tabular} & & & \\
\hline & & & & Employer satisfaction (0.32) & 88 & \begin{tabular}{|l|l|}
72 & 80 \\
\end{tabular} & & & \\
\hline & & & & Pass rate of English test (0.14) & 85 & \begin{tabular}{l|l}
82 & 74
\end{tabular} & & & \\
\hline
\end{tabular}

Figure 3 shows the comprehensive scores of the teaching quality of English departments in these three schools, their rank is $\mathrm{A}>\mathrm{B}>\mathrm{C}$, indicating that the teaching quality of English department of school $\mathrm{A}$ is the best, this assessment result is consistent with previous ranking result of the three schools, which shows that the proposed EIS is feasible and effective.

Besides assessing the overall teaching quality of a major, the proposed EIS can also analyze each specific index so that the school and department administrators can formula corresponding countermeasures for weak links. Therefore, the proposed EIS is not only applicable for horizontal comparisons among schools, but also suitable for the teaching quality assessment of the departments.

Figure 4 shows the assessment scores of the 5 primary indexes of the three schools, as can be seen from the figure, the comprehensive score of school A is higher, however, further analysis suggested that, although school A has a great advantage over the other two schools in terms of faculty level and teaching effect, still, it A has its disadvantages and shortcomings, for example, in terms of teaching condition, school A's score is lower than school B, and in terms of teaching process, school A's score is lower than school $\mathrm{C}$, therefore, school A needs to work on these two aspects. For 
school C, its scores in faculty and teaching effect are relatively low, therefore it needs to improve these two aspects.

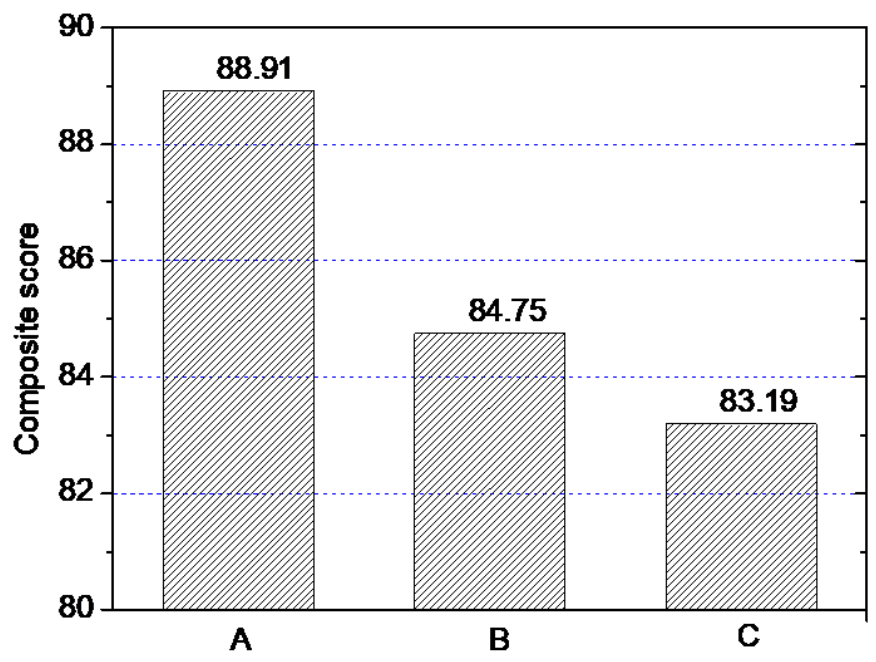

Fig. 3. Comprehensive scores of three schools

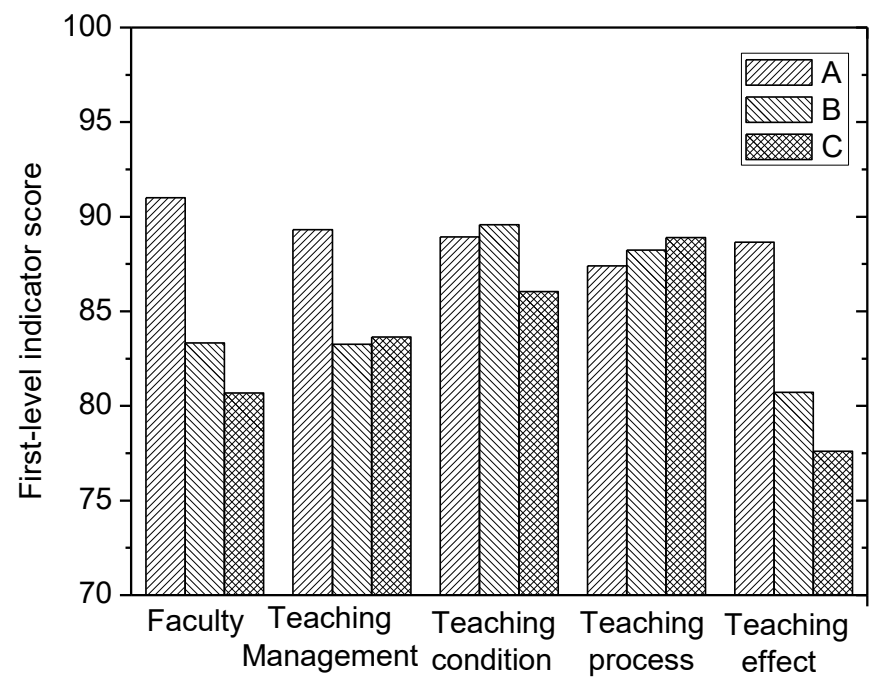

Fig. 4. Assessment scores of the 5 primary indexes of the three schools

Figure 5 shows the assessment scores of the 5 secondary indexes under the primary index teaching process of the three schools, as can be seen from the figure, school A's score in teaching method is the lowest, and school C's score in teaching method is the highest, through interview we found that in school A, teachers generally still adopt the traditional lecturing method, while in school C, the English department is carrying out 
course education reform, so their teaching methods are richer. In addition, school B's score in teaching content is significantly higher than school A and school $\mathrm{C}$, through interview we found that, the teaching content in schools $\mathrm{A}$ and $\mathrm{C}$ is mainly the textbooks, while in school B, the English department is working on constructing an application-type undergraduate discipline, it has developed their own English textbooks based on the original textbooks according to the professional talent cultivation goals and the market requirements, so its teaching content is more closely linked to students' real-life working and living applications. Moreover, for school A, in terms of the primary index teaching process, its scores in teaching method and teaching content are quite low, therefore the administrators and teachers of the English department of school A should pay close attention to this situation, and make efforts to enrich the teaching methods and teaching content.

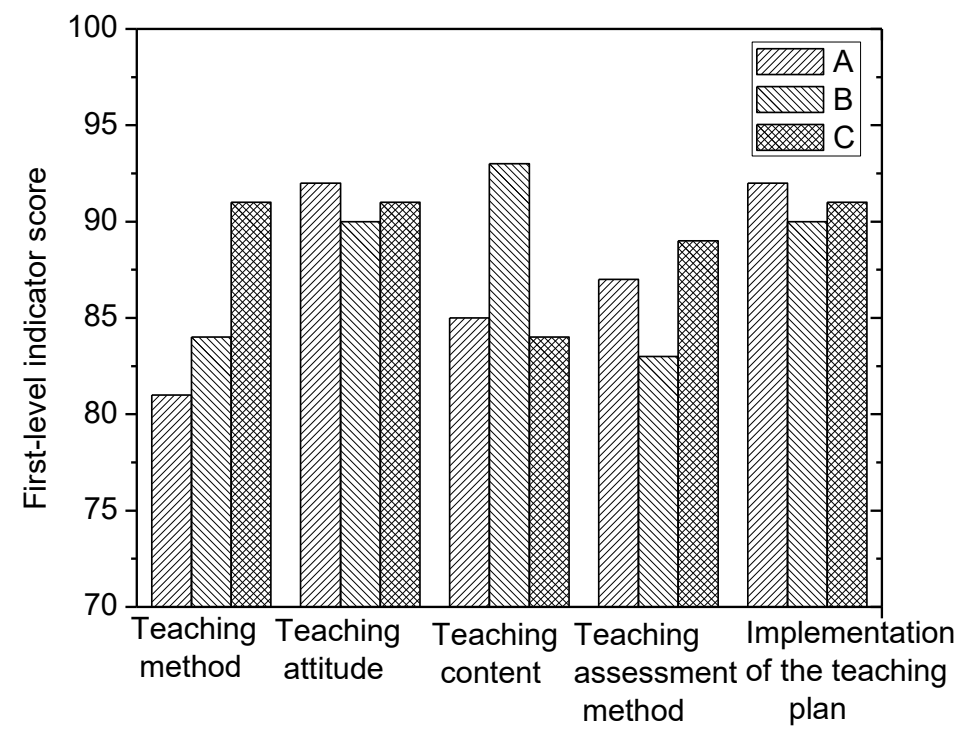

Fig. 5. Assessment scores of 5 secondary indexes under the primary index teaching process

\section{Conclusions}

Good teaching quality is the guarantee for the English departments of higher educational schools to cultivate English professionals and convey qualified talents to the society. This paper adopted the factor analysis method to analyze and research the assessment of teaching quality of college English department, and obtained the following conclusions:

1. To figure out the factors that can affect the teaching quality of college English department, this study conducted a questionnaire survey and interviews, then, based on the survey results and relevant references, this paper designed an EIS with 19 
indexes for assessing the said teaching quality and gave the detailed assessment content.

2. After sorting out and calculating the collected data using factor analysis, this study extracted 5 common factors and proposed an EIS with 5 primary indexes and 19 secondary indexes, also, the weight of each index was determined.

3. The English departments of 3 different types of higher educational schools were taken as research objects to conduct an empirical analysis on the proposed EIS, and the research results proved that the proposed EIS is feasible and effective, it not only can be used for the overall assessment of the teaching quality of colleges and universities, but also can analyze each specific index in detail, so that the schools and the English department administrators could formulate corresponding countermeasures for weak links.

\section{$5 \quad$ References}

[1] Ding, W. (2020). Influence of Road Traffic Noise on English Reading Comprehension of Chinese College Students Majoring in English, International Journal of Emerging Technologies in Learning, 15(14), 109-121. https://doi.org/10.3991/ijet.v15i14.15355

[2] Zhang, M. (2020). Virtual Situated Learning of Spoken English Based on Computer Simulation Technology, International Journal of Emerging Technologies in Learning, 15(4), 206-217. https://doi.org/10.3991/ijet.v15i04.12939

[3] Wang, Q. (2021). Research on teaching quality evaluation of college English based on the codas method under interval-valued intuitionistic fuzzy information. Journal of Intelligent and Fuzzy Systems, 1-10. https://doi.org/10.3233/jifs-210366

[4] Muthen, B., Kaplan, D. (2011). A comparison of some methodologies for the factor analysis of non-normal likert variables. British Journal of Mathematical \& Statistical Psychology, 38(2): 171-189. https://doi.org/10.1111/j.2044-8317.1985.tb00832.x

[5] Meredith, W. (1993). Measurement invariance, factor analysis and factorial invariance. Psychometrika, 58(4): 525-543. https://doi.org/10.1007/bf02294825

[6] Horn, J. L. (1965). Horn, J.L.: a rationale and test for the number of factors in factor analysis. Psychometrica, 30(2): 179-185. https://doi.org/10.1007/bf02289447

[7] Durak, H. B., Vatansever, K., Dalen, J. V., Vleuten, C. (2008). Factors determining students' global satisfaction with clerkships: an analysis of a two year students' ratings database. Advances in Health Sciences Education, 13(4): 495-502. https://doi.org/10.1007/ s10459-007-9061-7

[8] Grift, W. (2007). Quality of teaching in four European countries: a review of the literature and application of an assessment instrument. Educational Research, 49(2): 127-152. https://doi.org/10.1080/00131880701369651

[9] Leisyte, L., Enders, J., Boer, H. (2009). The balance between teaching and research in dutch and English universities in the context of university governance reforms. Higher Education, 58(5): 619-635. https://doi.org/10.1007/s10734-009-9213-1

[10] Spooren, P., Mortelmans, D., Christiaens, W. (2014). Assessing the validity and reliability of a quick scan for student's evaluation of teaching. results from confirmatory factor analysis and g theory. Studies in Educational Evaluation, 43: 88-94. https://doi.org/ 10.1016/j.stueduc.2014.03.001 
[11] Porto, M., Montemayor-Borsinger, A., López-Barrios, M. (2016). Research on English language teaching and learning in Argentina (2007-2013). Language Teaching, 49(3): 356-389. https://doi.org/10.1017/s0261444816000094

[12] Sandilos, L. E., Sims, W. A., Norwalk, K. E., Reddy, L. A. (2019). Converging on quality: examining multiple measures of teaching effectiveness. Journal of School Psychology, 74: 10-28. https://doi.org/10.1016/j.jsp.2019.05.004

[13] Ogawa, T., Haseyama, M. (2014). Adaptive missing texture reconstruction method based on kernel cross-modal factor analysis with a new evaluation criterion. Signal Processing, 103(1): 69-83. https://doi.org/10.1016/j.sigpro.2013.10.033

[14] Doherr, M. G., Carpenter, T. E., Wilson, W. D., Gardner, I. A. (1998). Application and evaluation of a mailed questionnaire for an epidemiologic study of corynebacterium pseudotuberculosis infection in horses. Preventive Veterinary Medicine, 35(4): 241-253. https://doi.org/10.1016/s0167-5877(98)00070-1

[15] Spanierman, L. B., Oh, E., Heppner, P. P., Neville, H. A., Mobley, M., Wright, C. V., Navarro, R. (2011). The multicultural teaching competency scale: Development and initial validation. Urban Education, 46(3): 440-464. https://doi.org/10.1177/0042085910377442

[16] Huang, J. (2021). An internet of things evaluation algorithm for quality assessment of computer-based teaching. Mobile Information Systems, 2021(13): 1-10. https://doi.org/10. $\underline{1155 / 2021 / 9919399}$

[17] Prosser, M., Trigwell, K. (2011). Confirmatory factor analysis of the approaches to teaching inventory. British Journal of Educational Psychology, 76(Pt2): 405-419. https://doi.org/10.1348/000709905x43571

[18] Prieto, L. R. (2012). Initial factor analysis and cross-validation of the Multicultural Teaching Competencies Inventory. Journal of Diversity in Higher Education, 5(1): 50. https://doi.org/10.1037/a0026199

[19] Flagler, S., Loper-Powers, S., Spitzer, A. (1988). Clinical teaching is more than evaluation alone! Journal of Nursing Education, 27(8): 342-348. https://doi.org/10.3928/0148-4834$\underline{19881001-04}$

\section{Authors}

Zhihao Wu, male, lecturer, was born on August 6, 1986, with a Master's degree majoring in Foreign Linguistics and Applied Linguistics. He is currently working as an English teacher at Cangzhou Normal University, Hebei Province, China. He has been teaching English courses more than 10 years, including College English, English Grammar, Cross-Cultural Communication. He has published several papers on English teaching and led several projects (email: czszlh@126.com).

Hui Li, female, associate professor, was born on July 13, 1975, in Cangzhou City, Hebei Province, China with a Master's degree majoring in English Linguistics and Literature. She is currently working as an English teacher at Cangzhou Normal University in Cangzhou, China. She has been teaching English courses for 24 years, including Intensive English, English Pedagogy, Journalism English, English Public Speaking, and oral English. She has published several papers on English teaching and led several provincial research projects and an important participant in several English MOOC courses circulating in China. She has been a visiting scholar to University of International Business and Economics for one year (2021). 
Xinyu Zhang, female, lecturer, was born on June14, 1990, with a Master's degree, majors in English Translation. She is currently working as an English teacher at Cangzhou Normal University in Cangzhou, China. She has been teaching Englishcourses for 8 years, including College English, Essential English and linguistics. She has published several papers on English teaching and led several projects (email: Zhang000xiny@163.com).

Zhili Wu, female, lecturer, was born on September 14, 1982, with a Master's degree, majors in Education. She is currently working as an English teacher at Cangzhou Technical College in Cangzhou, Hebei Province, China. She has been teaching English courses more than 10 years, including College English, English Grammar, Cross-Cultural Communication. She has published several papers on English teaching and led several projects (email: wuzhili198209@163.com).

Shuting Cao, female, lecturer, was born on October 10,1988, with a Master's degree, majors in English Translation. She is currently working in Cangzhou Normal University, which is located in Hebei Province, China. She has been teaching English courses for 5 years, including College English, Commercial English and CAT. She has published several papers on English teaching and translation, led over 10 projects at different levels (email: caoshuting1988@163.com).

Article submitted 2021-09-18. Resubmitted 2021-10-29. Final acceptance 2021-10-30. Final version published as submitted by the authors. 